\title{
Influence of auxin and sulfonylurea herbicides on seeded native communities
}

\author{
KENNETH LAIR AND EDWARD F. REDENTE
}

Authors are Restoration Ecologist, Ecological Research and Investigations Group, U.S. Bureau of Reclamation, P.O. Box 25007 (D-8220), Denver, Colo. 80225; and Professor, Forest, Rangeland and Watershed Stewardship Department, Colorado State University, Fort Collins, Colo. 80523. At the time of the research, the senior author was a doctoral graduate student, Rangeland Ecosystem Science Deparfment, Colorado State University, Fort Collins, Colo.

\author{
Abstract
}

Sulfonylurea herbicides were used extensively for weed control on Conservation Reserve Program (CRP) seedings, constituting over $98 \%$ of the residual herbicides applied from 1986-1990 in southeastern Colorado. Differences in species establishment were observed in CRP fields treated with sulfonylurea herbicides, suggesting that soils and climatic variation alone did not fully account for this establishment pattern. Impacts of 2 commonly used sulfonylurea herbicides and 2 auxin herbicides on establishment, inter-specific seedling competition and physiological response under CRP field conditions were evaluated. Seeded species were blue grama [Bouteloua gracilis (Willd). Ex Kunth) Lag. ex Griffiths], sideoats grama [Bouteloua curtipendula (Michx.) Torr.], western wheatgrass [Pascopyrum smith; (Rydb.) A. Love], switchgrass [Panicum virgatum L.], and sand dropseed [Sporobolus cryptandrus (Torr.) Gray]. Sulfonylurea herbicide application increased sideoats grama cover and live standing crop as much as $43 \%$ over auxin herbicide and mowing treatments, whereas switchgrass and western wheatgrass were reduced up to $71 \%$ by sulfonylurea treatment. Switchgrass cover was reduced by application of either sulfonylurea or auxin herbicides. Blue grama and sand dropseed were least affected by herbicide treatment. Auxin herbicide treatment resulted in $\mathbf{7 0 \%}$ increases in plant diversity for seeded species and total plant community over sulfonylurea treatment, primarily attributable to increased frequency of annual forbs. Seral stage was more advanced under sulfonylurea treatment, however, because of increased frequency, cover and live standing crop of perennial forbs, grasses, and half-shrubs.

Key Words: weed control, restoration, secondary succession, seedling competition, metsulfuron, chlorsulfuron, Conservation Reserve Program

The Conservation Reserve Program (CRP) was established in 1985 as Subtitle D of Conservation Title XII of the Food Security Act (Public Law 99-198, also known as the "Farm Bill") (Jones et al. 1997). Through enrollment in this program, CRP participants were provided with an annual rental payment plus costshare to assist in the establishment of permanent vegetative cover, in exchange for retiring highly erodible or environmentally

\footnotetext{
Research was funded by the USDA Natural Resources Conservation Service, Denver, Colorado. The authors wish to thank Dr. Terry McLendon and Dr. Michael Childress for assistance in statistical analysis.

Manuscript accepted 23 May 2003.
}

\section{Resumen}

Los herbicidas de sulfonilurea se usaron extensivamente para el control de maleza en las siembras del Programa de Conservación de Reserva (CRP), constituyendo mas del $98 \%$ de los herbicidas residuales aplicados de 1986 a 1990 en el sudeste de Colorado. En los terrenos del CRP tratados con herbicidas de sulfonilurea se observaron diferencias en el establecimiento de especies, sugiriendo que los suelos y las variaciones climáticas por si solas no explican totalmente este patrón de establecimiento. Se evaluaron los impactos de 2 de herbicidas de sulfonilurea comúnmente utilizados y $\mathbf{2}$ herbicidas de auxina en el establecimiento, competencia interespecifica y respuesta fisiológica bajo condiciones de campo en terrenos del CRP. Las especies sembradas fueron "Blue grama" [Bouteloua gracilis (Willd). Ex Kunth) Lag. ex Griffiths], "Sideoats grama" [Bouteloua curtipendula (Michx.) Torr.],"Western wheatgrass" [Pascopyrum smithii (Rydb.) A. Love], "Switchgrass" [Panicum virgatum L.] y "Sand dropseed" [Sporobolus cryptandrus (Torr.) Gray]. La aplicación de herbicidas de sulfonilurea incrementaron la cobertura de "Sideoats grama"y su biomasa viva en pie en $43 \%$ más que los herbicidas de auxina y los tratamientos de segado, mientras que el "Switchgrass y "Western wheatgrass" fueron reducidos hasta $\mathbf{7 1 \%}$ por los herbicidas de sulfonilurea. La cobertura de "Switchgrass"se redujo tanto por la aplicación de herbicidas de sulfonilurea como los de auxina. El "Blue grama" y "Sand dropseed"fueron los menos afectados por los tratamientos de herbicidas. El tratamiento de herbicidas de auxina resulto en un aumento del $70 \%$ de la diversidad de plantas de las especies sembradas y de la comunidad vegetal total sobre los herbicidas de sulfonilurea., esto es atribuible principalmente a un aumento en la frecuencia de hierbas anuales. El estado seral fue más avanzado bajo los tratamientos de herbicidas de sulfonilurea esto debido al incremento en la frecuencia, cobertura y biomasa viva en pie de las hierbas perennes, zacates y semi-arbustos.

sensitive cropland for 10 years (Osborn et al. 1995, Riddel et al. 1994). In Colorado, approximately 0.8 million hectares of cropland were enrolled in the CRP through 1990.

The difficulties of establishing perennial grasses on cultivated lands in eastern Colorado have been thoroughly documented (Wilson and Briske 1979, Hyder et al. 1971). Determination of species mixture combinations that promote similar seedling survival rates for all species in the mixture, however, has received much less study. Similarly, seedling ecology and competitive relationships among native species when seeded in common mix- 
tures have not been well documented, especially in response to management inputs (Francis and Pyke 1997, Kline and Howell 1987).

In addition to knowledge gaps on seedling ecology and competitive relationships among seeded species, few studies have documented the long-term effects of herbicide application in terms of establishment and productivity of seeded native grasses. Herbicides having amino acid (acetolactase synthase; ALS) inhibition as their primary mode of action (Zimdahl 1993) are receiving increased use in this regard. These applications include use of herbicides such as chlorsulfuron $\{2$ chloro-N-[[(4-methoxy-6-methyl-1,3,5-triazin-2-yl)amino]carbonyl]benzene sulfonamide $\}$, metsulfuron $\{2-[[[[14-$ methoxy-6methyl-1,3,5-triazin-2-yl)amino]carbonyl]amino]sulfonyl] benzoic acid\}, sulfometuron $\{2$-[I[[ $(4,6$-dimethyl-pyrimidinyl)amino]carbonyl]-amino ]sulfonyl]benzoic acid\}, clopyralid \{3,6-dichloro-2-pyridine carboxylic acid $\}$ and imazapyr $\{( \pm)-$ 2 - [4, 5-d ih y d ro- 4 - me t h y $1-4-(1-$ methylethyl)-5-oxo- $1 H$ imidazol-2-yl]-3pyridinecarboxylic acid\} (Whitson and Koch 1998, Ferrell et al. 1998, Lym 1998).

These studies primarily addressed impacts on cool-season, introduced grass establishment and production. Additionally, research emphasized performance of grasses in single species trials, rather than in mixtures allowing simultaneous study of the influence of interspecific competition on herbicide treatment response. Research of this latter type also has rarely been conducted on native, warm-season grasses.

Sulfonylurea herbicides were used extensively on Kiowa County, Colo. CRP seedings, constituting over $98 \%$ of the residual herbicides applied. Wide disparity in establishment between species and greater dominance of sideoats grama [Bouteloua curtipendula (Michx.) Torr.; BOCU] ${ }^{1}$ observed in CRP fields treated with sulfonylurea herbicides suggests that soils and climatic variation alone do not fully account for these results. Comprehensive field research in the western Great Plains region evaluating longterm response of cool- and warm-season, native seeded grasses to sulfonylurea chemistry (with recent labeling for revegetation uses) has not been documented. The objective of this research was to evaluate

${ }^{1}$ Common and scientific names for plants according to nomenclature from the USDA-NRCS PLANTS Database (USDA,NRCS 2001). the impact of 2 commonly used sulfonylurea residual herbicides in comparison with 2 auxin herbicides on establishment, inter specific seedling competition and physiological response under CRP field conditions.

\section{Materials and Methods}

\section{Study Area}

The research was conducted in Kiowa County in southeastern Colorado (County Seat: Eads, $38.48^{\circ} \mathrm{N} 102.78^{\circ} \mathrm{W}$ ). Mean annual precipitation ranges from $30.5 \mathrm{~cm}$ in the southwestern portion of the county to $40.6 \mathrm{~cm}$ in the northeastern portion. Approximately $77 \%$ or $28.5 \mathrm{~cm}$ of the total annual precipitation falls in the form of rain during the mean 160-day growing season of late April through September (Anderson et al. 1981). The 1986-87 seeding year was an extremely favorable year, with annual (January-December, 1987) precipitation $35.4 \%$ above the long-term mean annual precipitation. In contrast, the 1987-88 seeding year was unfavorably dry, with annual precipitation $10.5 \%$ below the long-term annual mean. Mean monthly air temperatures for the 2 seeding years were near the long-term mean.

Comprehensive data covering all aspects of planned and applied CRP seeding technology were compiled for all CRP fields and entered into a database using CRP contracts on file with the Natural Resources Conservation Service (NRCS) in Kiowa County. Data were obtained directly from 401 CRP contracts countywide, representing 843 fields and 70,870 ha. Field size ranged from 0.7 to 207.3 ha, with a mean field size of 33.6 ha. Field data collection was conducted from June, 1994 through January, 1995, yielding vegetative stand ages of 7 and 8 years for the 1987-88 and 1986-87 seeding years, respectively.

\section{Herbicide Chemistry and Application Rates}

Three categories were inclusive of all weed control practices applied: a) mowing (non-herbicide control); b) non-residual growth regulator (auxin) herbicides only; and $\mathrm{c}$ ) residual (sulfonylurea) herbicides only. Mowing was conducted as a nonherbicide option to prevent viable weed seed formation and reduce competition with seeded vegetation, with repeat applications as necessary during the growing season. Auxin herbicides (hormonal plant growth inhibitor) included butyl ester, low-volatile ester, and amine formulations of 2,4-D \{(2,4-dichlorophenoxy)acetic acid $\}$, and the benzoic acid dicamba $\{3,6-$ dichloro-2-methoxybenzoic acid\}. These herbicides were applied primarily in tankmix combinations, with few applications of 2,4-D alone and no applications of dicamba alone. Typical labeled application rates were $0.56-0.84 \mathrm{~kg} \mathrm{ha}^{-1}(0.5-0.75 \mathrm{lb}$ $\left.\mathrm{ac}^{-1}\right)$ and $0.14-0.22 \mathrm{~kg} \mathrm{ha}^{-1}(0.125-0.25 \mathrm{lb}$ $\mathrm{ac}^{-1}$ ) for 2,4-D and dicamba, respectively. Timing of application was typically postemergence during early vegetative weed growth stages.

Residual herbicides were of sulfonylurea herbicide chemistry, which included metsulfuron and chlorsulfuron. Metsulfuron 12[I[[(4-methoxy-6-methyl-1 ,3,5-triazin-2yl)amino]carbonyl]amino]-sulfonyl]benzoic acid\} (ALLYTM, ESCORT TM) exhibits both foliar contact and residual soil activity, with short-to-moderate residual life in the soil, exhibiting a mean field half-life of approximately 30 days (range of 1-6 weeks) (Brown and Cotterman 1994, Wauchope et al. 1992).

Chlorsulfuron $\{2$-chloro-N-[[( 4methoxy-6-methyl-1,3,5-triazin-2yl)amino ]carbonyl]benzene 5 sulfonamide \} (GLEAN'M , TELARTM) is a compound very similar in mechanism of action to metsulfuron. Chlorsulfuron relies more heavily on root uptake than metsulfuron, having less foliar contact activity and being more dependent on soil moisture to activate, release and mobilize the chemical within the root zone (Walker et al. 1989). Chlorsulfuron exhibits longer residual soil activity, with a mean field half-life of approximately 40 days (range of 4-7 weeks), although chlorsulfuron residues may remain in the soil and injure susceptible plants for $1-4$ years after application in high pH (>7.5) soils (Brown and Cotterman 1994, Wauchope et al. 1992, Walker et al. 1989, Beyer et al. 1988). Metsulfuron was applied post-emergence at the labeled rate of $7.0 \mathrm{~g} \mathrm{ha}^{-1}\left(0.1 \mathrm{oz} \mathrm{ac}^{-1}\right)$. Chlorsulfuron was applied primarily pre-plant (late fall or early winter) at the labeled rate of $23.1 \mathrm{~g}$ ha $(0.33$ oz $\left.\mathrm{ac}^{-1}\right)$.

\section{Species Selection}

Five grass species were evaluated for establishment success in relation to the effects of herbicide application: blue grama [Bouteloua gracilis (Willd. ex Kunth) Lag. ex Griffiths; BOGR2], sideoats grama [BOCU], western wheatgrass [Pascopyrum smithii (Rydb.) A. Love; PASM], switchgrass [Panicum virgatum L.; PAVI2], and sand dropseed [Sporobolus cryptandrus (Torr.) Gray; SPCR]. All CRP seedings were applied as 
mixtures of at least 3 species to maximize vegetative stand establishment success and minimize potential impacts of adverse weather, disease, or insect damage on anyone species. Western wheatgrass was included rarely and only in small amounts in seed mixtures applied to sandy soils (sandy loam, loamy sand) in Kiowa County. As a result of insufficient sample size for seedings of western wheatgrass on these sandy soils, this species was evaluated only on loam soils (loam, silt loam). Non-seeded species were also identified and recorded during the vegetation sampling.

Establishment (Response) Variables

Response variables were above-ground plant attributes considered useful for monitoring degree of seeding establishment success, productivity, vigor and persistence (competitive ability) (Bonham 1989, McGinnies et al. 1988, Cook and Stubbendieck 1986). Spatial and production variables included cover measurements [bare ground, litter, basal and canopy; (\%)], and live standing crop ( $\left.\mathrm{kg} \mathrm{ha}^{-1}\right)$. Vigor variables included mean leaf height $(\mathrm{cm})$, inflorescence count (no), and inflorescence height (em). Litter was subdivided into persistent litter (dead plant material that was still attached to the plant crown and maintaining an erect or semi-erect orientation above the soil surface), and non-persistent litter (dead plant material lying flat on the soil surface and unattached to any plant crown).

A diversity index was computed to provide estimates of vegetative biodiversity. A modification of Simpson's Index (Simpson 1949) was used such that:

where:

$$
\mathrm{D}=1 \underset{\mathrm{i}=1}{\underset{\sum}{\mathrm{s}}\left(\mathrm{P}_{\mathrm{i}}\right)^{2}}
$$

$\mathrm{D}=$ diversity index indicating the probability of picking 2 plants at random from a plant community (population) that are different species (scale of $0-1)$

$\mathrm{P}_{\mathrm{i}}=$ the proportion of individuals of species $i$ in a community of $s$ species.

Species proportions $\left(\mathrm{P}_{\mathrm{i}}\right)$ for use in the Simpson's Index were taken from basal cover percentages converted to relative frequency percentages from the transect point-samples. Indices were computed to provide estimates of diversity for 2 nested plant communities: seeded species only, and all species encountered (seeded and non-seeded).

\section{Field Sampling Methods}

Point sampling was performed in each sampled CRP field for all cover variables along 4 randomly located 25-meter transects at $\mathbf{0 . 5}$-meter intervals, yielding 50 sample points per transect. Live standing crop, mean leaf height, mean inflorescence count, and mean inflorescence height were measured using $1.0 \mathrm{~m}^{2}$ quadrats placed at 2 random locations along each transect. All species (seeded and non-seeded) within the quadrat frame were individually harvested at approximately a $2.5 \mathrm{~cm}$ height above the soil or plant pedestal surface. The material was air-dried for 2 weeks under ambient air conditions. Leaf and inflorescence height were measured from the soil surface to the top of the predominant height grouping for each plant organ. Current year inflorescences were counted for each seeded species, typically at expansion stage or later. Total sample size was $n=240$ transects $(60$ fields; 12,000 sample points, $4801.0 \mathrm{~m}^{2}$ quadrats).

\section{Statistical Analysis}

Univariate and multivariate statistical analysis procedures were applied to the data to test for significance of dependent variable responses to treatment for single species and species groups (plant communities), respectively. The analyses were conducted in accordance with univariate procedures described in Gomez and Gomez (1984) and Steel and Tome (1980), and multivariate procedures described in Manly (1994) and Afifi and Clark(1984). The BMDP statistical software package (BMDP Statistical Software, Inc., Los Angeles, Calif.; Dixon 1992) was used to perform all statistical analyses.

Three-way ( $3 \times 2 \times 2)$ factorial analysis of variance (ANOVA; BMDP-2V) was used to evaluate herbicide main effect and interactions with soil texture and seeding year. Fisher's Protected LSD (Steel and Torrie 1980) was used for mean separations $(P=0.05)$. To minimize variance of a treatment mean, sample size can be increased or the variance in the sampled population controlled (Steel and Torrie 1980). In an observational study such as this where initial experimental design could not be controlled, covariates that had probability of affecting treatment outcomes were identified and evaluated for contribution to treatment effects through ANOVA procedures. These covariates included cover crop type, preparatory tillage, drill type/equipment, grass cultivar, major land resource area (precipitation zone), seeding season, PLS seed qual- ity, species mixture composition, and prior field erosion history. Initial runs of ANOVA for each species/cover type and response variable included all covariates. Covariates that were shown to have insignificant correlations $(P>0.05)$ with the response variable were pooled with the error term. The ANOVA was then repeated until only covariates showing consistent, significant correlation with the response variable remained for final statistical adjustment of herbicide treatment means.

Multivariate procedures analyzed responses to herbicide treatment using plant community attributes (i.e., multiple species and response variables evaluated simultaneously under a common Type-I error). Multivariate analyses included quadratic discriminant analysis (BMDP 5M) and stepwise linear discriminant analysis (BMDP-7M). Quadratic discriminant analysis (QDA), similar in nature to multivariate ANOVA, was used to evaluate group differences between treatment levels as an initial screening procedure to determine true treatment differences employing all possible variables (Dixon 1992, Afifi and Clark 1984). Discriminant analysis procedures utilize $\mathrm{F}$-statistics for tests of group mean differences, and thus are considered relatively robust in relation to data normality and homogeneity of variance (Bonham 1992). Mahalanobis $D^{2}$ values and matrix Approximate F-values with associated probability $(P)$ values generated by the discriminant analysis were used to determine significance of differences for pairwise comparisons of group treatment means. Mahalanobis distances are algebraic representations of the relative means of squared distances of each case (sample) from the mean of all cases as grouped by SDA (Dixon 1992). Initial treatment groupings that were not significantly different were pooled and the analysis repeated on the modified data set until all remaining groups were significantly different at $\mathrm{P}<0.05$.

Stepwise linear discriminant and canonical analysis (BMDP-7M) were performed to reduce the number of response variables needed to account for the majority of the variation. These procedures were used to detect differences between treatments using dependent variables combined as multivariate groupings. Multivariate tests evaluate treatment differences based on multi-dimensional group means, limiting the probability of type I error to the test as a whole regardless of number of variables. These tests also provide greater power to detect treatment response differences in 
multiple plant community attributes (Manly 1994).

Canonical variates representing independent, linear combinations of response variable subsets (similar to multiple linear correlation equations) were generated by the analysis to provide 2-dimensional foci for final multivariate treatment groupings, and to illustrate extent of mean group separations. These equations can also serve as variable groupings for classification of new cases (samples) into group association when prior treatment is unknown (Afifi and Clark 1984, McLendon and Dahl 1983). Standardized correlation coefficients were used to illustrate the magnitude of canonical variate loadings for each of the selected response variables, to provide maximum discriminant power among groups, and enable maximum multiple correlation $\left(R^{2}\right)$ with the independent variable (herbicide treatment type) (Afifi and Clark 1984). Plots (with $95 \%$ confidence intervals, Mahalanobis $\mathrm{D}^{2}$ values, and Approximate F-values) of the first 2 canonical variates were used to graphically depict final treatment groupings.

\section{Results}

\section{Univariate Analysis}

Metsulfuron and chlorsulfuron were grouped as a common methodology and treatment type because of: 1) their closely related sulfonylurea (SU) chemistry and modes of action; 2) anticipated similar response to soil environmental variables of moisture, temperature, clay content and $\mathrm{pH}$; 3) their observed similar impact on seeded species composition; and 4) little difference in actual effect upon seeded grasses when analyzed separately using ANOVA with covariate analysis. Results of the analysis were consistent with the behavior of the SU herbicides as a grouped class. Therefore, it was not considered necessary or effective to split the 2 SU herbicides for evaluation of herbicide treatment effect in comparison with auxins and mowing. Seeded species responded differently to herbicide treatment for most response variables (Fig. 1). Sideoats grama exhibited positive responses to sulfonylurea herbicide treatment, with increases ranging from $14 \%$ to $43 \%$ over auxin and mowing treatment for basal and canopy cover, live standing crop, and live standing crop as percent relative composition of total seeded live standing crop.

Switchgrass and western wheatgrass were adversely affected by sulfonylurea
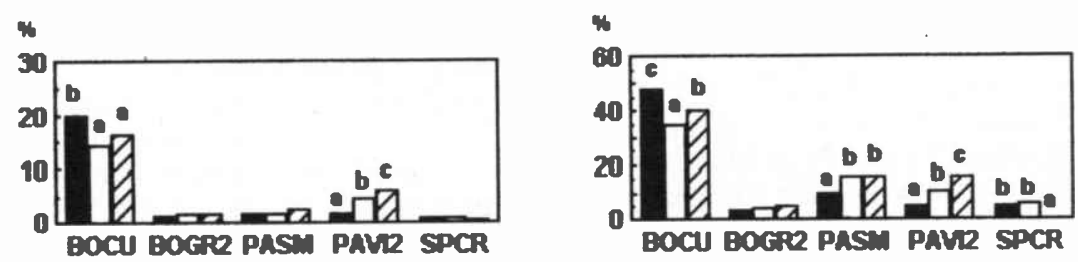

UNE STANDMG CROP

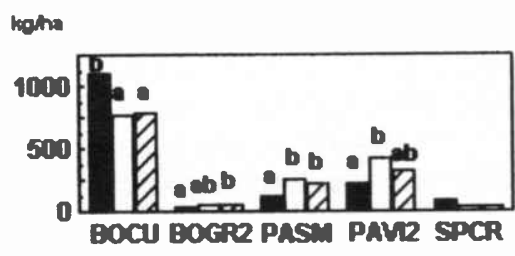

LENF MEGHT
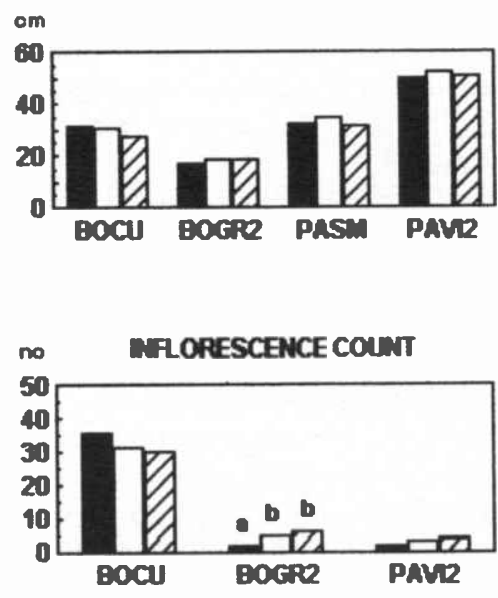

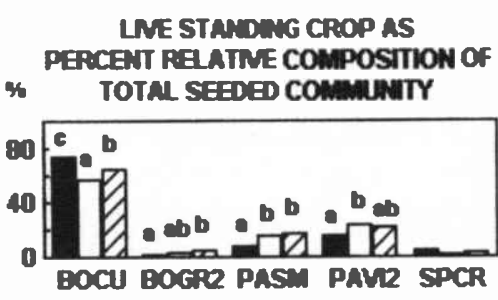

WALORESCENCE HEGHT

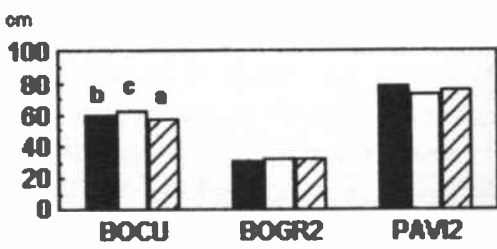

\begin{tabular}{|ll|}
\hline DSULFOMUREA D MUXIN D MOWNO \\
\hline BOCU & sideoats grama \\
BOCR2 & blue grama \\
PASM & westem wheatgrass \\
PAYR & switchgrass \\
BPCR & sand dropseed \\
\hline
\end{tabular}

Fig. 1. Herbicide and mowing treatment means for the 5 study species for cover, live standing crop, and plant vigor variables. Bar sets with different letters within a species are significantly different at the $\mathbf{P}<\mathbf{0 . 0 5}$ level using Fisher's Protected LSD mean separation. Absence of letters indicates no differences. Inflorescence count and inflorescence height were not evaluated for western wheatgrass (PASM). Vigor variables were not evaluated for sand dropseed (SPCR).

herbicide application, contrary to the hypothesis that sulfonylurea herbicide treatment would benefit all seeded species. Western wheatgrass canopy cover, live standing crop, and relative composition (based on live standing crop) were reduced under sulfonylurea herbicide treatment, ranging from $37-39 \%, 42-49 \%$, and $49-55 \%$, respectively, below auxin or mowing treatments (Fig. 1). Switchgrass incurred severe adverse impacts under sulfonylurea herbicide use, producing stand reductions ranging from $61-71 \%, 51-69 \%$, $28-47 \%$, and $27-32 \%$ for basal cover, canopy cover, live standing crop, and relative composition, respectively. Auxin herbicides also significantly reduced basal cover and canopy cover for switchgrass compared to mowing.
Few differences between herbicide treatments were detected for responses of blue grama and sand dropseed (Fig. 1). Blue grama exhibited small increases in live standing crop and relative composition (based on live standing crop) when mowing was applied, while sand dropseed responded positively to herbicide treatment for canopy cover only. The high degree of variability in these 2 species, resulting from poor or erratic establishment across all treatments, may have precluded additional treatment differences.

Auxin herbicide treatments produced few univariate differences in basal and canopy cover and live standing crop compared to mowing for most species (Fig. 1). Where differences existed between these 2 treatments, results were variable. Auxin 
Table 1. Univariate effeets of herbicide treatment for the total plant community.

\begin{tabular}{|c|c|c|c|c|c|c|}
\hline \multirow[b]{2}{*}{$\begin{array}{l}\text { Response } \\
\text { Variable }^{1}\end{array}$} & \multirow[b]{2}{*}{$\begin{array}{c}\text { Treatment } \\
\text { Type }^{2}\end{array}$} & \multicolumn{5}{|c|}{ Cover Type } \\
\hline & & $\begin{array}{l}\text { Bare } \\
\text { Ground }\end{array}$ & $\begin{array}{c}\text { Non- } \\
\text { Persistent } \\
\text { Litter }\end{array}$ & $\begin{array}{l}\text { Persistent } \\
\text { Litter }\end{array}$ & $\begin{array}{l}\text { Seeded } \\
\text { Species }\end{array}$ & $\begin{array}{c}\text { All } \\
\text { Species }\end{array}$ \\
\hline$\overline{\mathrm{BC}}(\%)$ & $\begin{array}{l}\text { SU } \\
\text { AU } \\
\text { MOW }\end{array}$ & $\begin{array}{l}22.4 a^{3} \\
28.9 b \\
32.4 b\end{array}$ & $\begin{array}{l}37.9 \mathrm{a} \\
36.1 \mathrm{a} \\
35.3 \mathrm{a}\end{array}$ & & $\begin{array}{l}25.9 \mathrm{~b} \\
23.9 \mathrm{ab} \\
22.3 \mathrm{a}\end{array}$ & $\begin{array}{l}26.3 \mathrm{~b} \\
27.1 \mathrm{~b} \\
23.1 \mathrm{a}\end{array}$ \\
\hline $\mathrm{CC}(\%)$ & $\begin{array}{l}\text { SU } \\
\text { AU } \\
\text { MOW }\end{array}$ & & & $\begin{array}{r}13.5 \mathrm{~b} \\
9.3 \mathrm{a} \\
10.1 \mathrm{a}\end{array}$ & $\begin{array}{l}70.8 \mathrm{~b} \\
65.9 \mathrm{a} \\
64.2 \mathrm{a}\end{array}$ & $\begin{array}{l}74.9 \mathrm{~b} \\
68.4 \mathrm{a} \\
69.6 \mathrm{a}\end{array}$ \\
\hline $\begin{array}{l}\text { LSC } \\
\left(\mathrm{kg} \mathrm{ha}{ }^{-1}\right)\end{array}$ & $\begin{array}{l}\text { SU } \\
\text { AU } \\
\text { MOW }\end{array}$ & & & & $\begin{array}{l}1525.3 \mathrm{~b} \\
1420.6 \mathrm{~b} \\
1213.2 \mathrm{a}\end{array}$ & $\begin{array}{l}1576.0 \mathrm{~b} \\
1450.4 \mathrm{~b} \\
1283.9 \mathrm{a}\end{array}$ \\
\hline DI & SU & & & & $0.27 \mathrm{a}$ & $0.29 \mathrm{a}$ \\
\hline & $\begin{array}{l}\text { AU } \\
\text { MOW }\end{array}$ & & & & $\begin{array}{l}0.46 \mathrm{c} \\
0.38 \mathrm{~b}\end{array}$ & $\begin{array}{l}0.48 \mathrm{~b} \\
0.44 \mathrm{~b}\end{array}$ \\
\hline
\end{tabular}

Variable code key: $\mathrm{BC}=$ basal cover; $\mathrm{CC}$ = canopy cover; $\mathrm{LSC}=$ live standing crop; $\mathrm{DI}=$ diversity index.

${ }_{3}^{2}$ Treatment code key: $\mathrm{SU}=$ sulfonylurea herbicide; $\mathrm{AU}=$ auxin herbicide; $\mathrm{MOW}=$ mowing.

${ }^{3}$ Means with different letters within a cover type for a given response variable are signifieantly different at the $P=0.05$ level of significance using LSD mean separation.

herbicides proved detrimental to sideoats grama and switchgrass canopy cover (12\% and $36 \%$ reduction, respectively), whereas both auxin and sulfonylurea herbicides increased sand dropseed canopy cover. Decreased canopy cover for sideoats grama under auxin herbicide treatment was not reflected in live standing crop, however. Basal cover exhibited the least response to all herbicide treatments across species.

For vigor variables of leaf height, inflorescence height and inflorescence count, the impact of sulfonylurea herbicides was much reduced (Fig. 1). Sulfonylurea herbicides diminished inflorescence height for sideoats grama, and reduced inflorescence count only for blue grama. Responses of vigor variables to sulfonylurea herbicides for all other seeded species generally were not different from auxin herbicides and mowing.

Treatment differences among total cover and production variables for the plant community (seeded species only, and all species combined) corresponded closely to univariate results for sideoats grama alone (Table 1). Sulfonylurea herbicide treatment significantly reduced bare ground, arid increased persistent litter, basal cover, and canopy cover of the plant community compared to auxin herbicides and mowing. Reductions in bare ground of $31 \%$ and $11 \%$ over auxin and mowing, respectively, resulted from sulfonylurea herbicide treatment, while canopy cover increased by $10 \%$ over non-sulfonylurea treatments. Non-persistent litter was unaffected by herbicide treatment. Live standing crop responded positively to herbicide treatment in general (in comparison to mowing for seeded species and the total prant community).
Diversity index (DI) was increased for seeded species and all species under nonsulfonylurea herbicide treatment (Table 1). Sulfonylurea herbicide treatment resulted in the least plant diversity among seeded species and for the total plant community, attributed primarily to the dominance of sideoats grama under this treatment. Auxin herbicide treatment resulted in $70 \%$ and $66 \%$ increases in diversity over sulfonylurea herbicide treatments for seeded species and all species combined, respectively. Both number of species and frequency of occurrence of non seeded species encountered were consistently highest in fields not treated with sulfonylurea herbicides. Although species diversity was increased for all species combined, proportional increase remained essentially the same as with seeded species only, largely because of the effect of increased diversity of the seeded species.

\section{Multivariate Analysis}

Quadratic discriminant analysis (QDA) revealed more numerous and consistent differences among the herbicide and mowing treatments than resulted from univariate analysis of plant community totals alone. Stepwise linear discriminant analysis (SDA) was employed subsequent to QDA to detect treatment differences using a reduced subset of response variables that serve as key indicators of multivariate treatment response. The SDA procedure selects these reduced subset variables based on their representation of the majority of variability in multivariate response to treatment. The results of QDA indicated that analysis of individual seed mixtures did not increase our ability to detect differ- ences between group responses. Therefore, SDA was applied only to response variable subsets without regard to seed mixture composition. Analysis of response variable classes (i.e. basal cover, canopy cover, live standing crop) was retained in order to assess similarity of minimum variable sets selected by SDA across these classes.

Highly significant differences were detected between all 3 treatments for all variable subsets except live standing crop (Fig. 2). Multivariate group (2-dimensional) means represented by the first 2 canonical variates generated from the SDA are depicted for each variable subset class. The first canonical variate provides the most interpretive meaning of the discriminant analysis because it accounts for the majority of the variability of the multivariate observations (Afifi andClark 1984). Although relative Mahalanobis $\mathrm{D}^{2}$ distances between multivariate group means differed somewhat between evaluation scenarios (variable subsets), relative magnitudes (or relationships) of $\mathrm{D}^{2}$ distances between groups remained similar. No group differences were detected between auxin herbicide and mowing treatments for live standing crop.

Sideoats grama basal and canopy cover and live standing crop, and total plant community bare ground consistently received highest canonical variate loadings for the first canonical variate, and highest F-values for inclusion as indicator variables used to distinguish treatment differences. As illustrated in Figure 2, separation of sulfonylurea herbicide treatment effects from those of auxin herbicide and mowing was revealed by the first canonical variate. This separation relies primarily on the aforementioned sideoats grama/bare ground contrast, where sulfonylurea herbicide treatment typically produced higher sideoats grama cover and lower bare ground percentages. As indicated by rankings of the canonical variate coefficient loadings, the key indicator variables of sideoats grama canopy cover (Fig. 1) and total plant community bare ground (Table 1) appear to be most significant and utilitarian in distinguishing effects of herbicide treatment on Kiowa County CRP fields. This finding is consistent with observations that cover provides the best index of species dominance (Taylor 1986), and that canopy cover is perhaps the most important single parameter of a species affecting its community ecology (Daubenmire 1959).

When plant community totals only were analyzed, bare ground retained its high canonical loading. Bare ground was com- 
ALL POSSIBLE VARIABLES

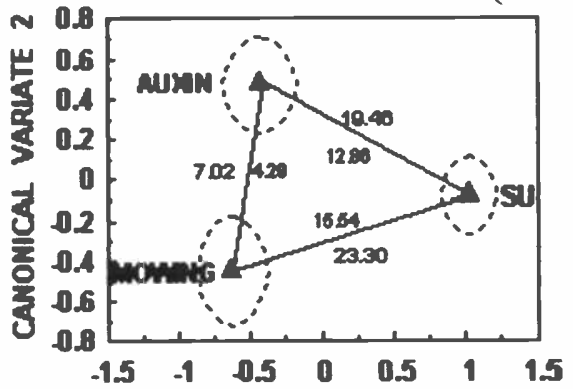

BASAL COVER

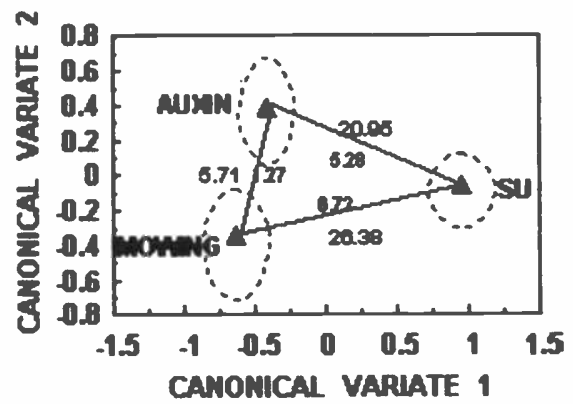

ALL COVER + LNE STANDING CROP

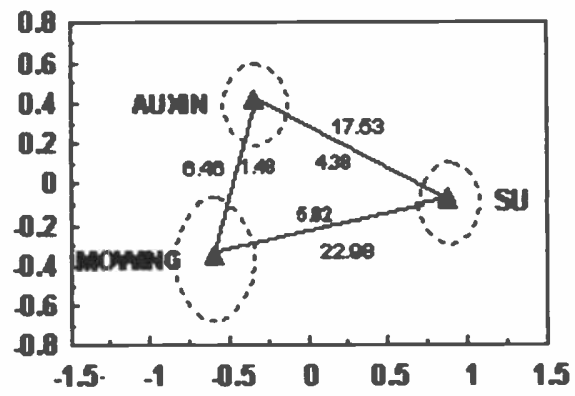

CAMOPY COVER

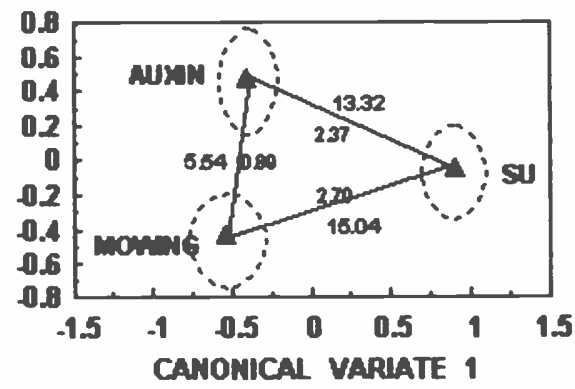

LNE STANDING CROP

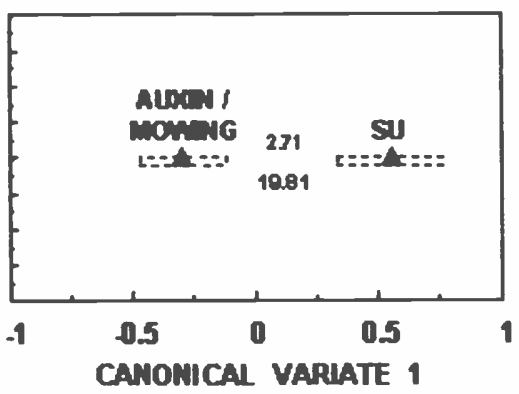

Fig. 2. Canonical variate means, $95 \%$ confidence intervals (circles), F-values (outside the connecting lines), and Mahalanobis $\mathrm{D}^{2}$ values (inside the connecting lines) for herbicide and mowing treatments derived from stepwise discriminant analysis. Auxin and mowing treatment groups for live standing crop variables were pooled, resulting in only one canonical variate. All F-values are highly significant at $\mathbf{P}<0.001$. SU = sulfonylurea.

bined with diversity index variables rather than cover or live standing crop variables, however, as the primary indicators of treatment effect. The contrast between total species diversity and seeded species diversity also received highest canonical loadings in the second canonical variate. These findings suggest that herbicide treatment response for the plant community as a whole may be more accurately determined by augmenting cover and live standing crop measurements with estimates of plant diversity.

Basal and canopy cover variables for switchgrass, blue grama, western wheatgrass, and sand dropseed were more highly and equally weighted in the second canoni-

cal variate (Fig. 2; Y-axis). Accordingly, these variables demonstrated significant separation of auxin herbicide and mowing effects. Switchgrass and sand dropseed cover variables most frequently combined to have the dominant effect upon treatment differentiation between these 2 types. Auxin herbicide treatment was typified by relative higher percentages of sand dropseed cover, while mowing treatments exhibited higher percentages of cover for switchgrass.

The contribution of blue grama and western wheatgrass in determining multivariate responses to herbicide treatment was relatively minimal, although significant as indicated by the approximate F- value. The most equally weighted contribution of response variables from all seeded species for either canonical variate was the variable subset for canopy cover. The live standing crop subset yielded the fewest indicator variables for distinguishing treatment differences.

\section{Discussion}

Differential response among the seeded species between sulfonylurea herbicide, auxin herbicide and mowing treatments may have resulted from several factors. Direct toxicity to certain seeded grasses may be a possible cause (Wilson 1995, Bovey and Hussey 1991, personal communications from G. Beck, R. Bovey, R. Shimabukuro). Injury to cool-season grasses and Old World bluestems by sulfonylurea herbicides has been documented (Darwent and Clayton 1994, Ogg et al. 1994, Conrad 1990). Warm-season grasses commonly used in CRP applications have been injured by imazethapyr \{2-[4,5-dihydro-4-methyl-4-(1-methylethyl)-5-oxo-l H imidazol-2-yl\}-5-ethyl-3-pyridinecarboxylic acid\}, a herbicide with similar mechanism of action in plants to sulfonylureas (Wilson 1995), and high rates of chlorsulfuron (Bovey and Hussey 1991). Sulfonylurea herbicides have been shown in unpublished field trials to cause galls, stunted growth, and curling deformation of root systems in switchgrass (G. Beck, personal communication). Forage yield of native mixed-grass rangeland in western Nebraska was unaffected, however, by application of chlorsulfuron at $20.0 \mathrm{~g} \mathrm{ha}^{-1}$ for control of leafy spurge (Stougaard et al. 1994).

The effects of sulfonylurea herbicides on seedling grass germination and development have not been well established (Bovey and Hussey 1991). Differential physiological susceptibility to herbicides (e.g., atrazine) in many grasses has been attributed to differences in metabolic routes between species by which herbicides are detoxified or inactivated (Knight et al. 1993, Weimer and Swisher 1985). The same mechanisms may also account for the differential response between the seeded species to sulfonylurea herbicide treatment if direct herbicide phytotoxicity is indeed adversely affecting species such as western wheatgrass and switchgrass (Machac 1995, Brown et al. 1991, Goatley et al. 1991). Although use of residual herbicides provides the most effective means of attaining extended periods of weed suppression during the critical seedling 
establishment period, the negative response of both switchgrass and western wheatgrass to sulfonylurea herbicide treatment suggests that possible direct toxicity to these species may have played a role in ultimate plant community composition.

Alternatively, sulfonylurea herbicides may have provided superior weed control and favorable soil moisture conditions early in the growing season, enabling sideoats grama to establish dominance over the other seeded species because of its superior competitive abilities. Sideoats grama is vegetatively aggressive in terms of rapid, seasonally early, deep root extension (Downs and Niner 1963, Olmstead 1942, 1941); rapid basal crown spread through tiller increase; rapid vegetative and reproductive culm internode elongation; and relatively short $(3 \mathrm{~cm})$, protected growing points on vegetative culms (Sims et al. 1971). Sideoats grama exhibits high seedling vigor across all cultivars, more than many other warm-season native grasses commonly used in revegetation efforts in the central Great Plains region (Tober and Chamrad 1992, Heizer and Hassell 1985).

The overriding influence of sideoats grama's highly positive response to sulfonylurea herbicide treatment may tend to mask plant community response, especially for sub-dominant species. Multivariate discriminant analysis, however, provided indication that changes in cover, live standing crop, relative composition (based on live standing crop), and diversity indices for seeded species other than sideoats grama and non-seeded species are also reflected in treatment responses. This result was useful in distinguishing between effects of auxin herbicide and mowing treatments.

The adverse effects of auxin herbicide treatment on cover of sideoats grama and switchgrass is consistent with results reported by Bovey and Hussey (1991), who found these species susceptible to injury from auxin-based herbicides during seedling growth stages. An additional reason for reduced performance of auxin herbicides may have been poor timing of auxin herbicide application in relation to weed vigor, growth stage, and favorable soil moisture conditions. Mowing services (typically provided by the operator) were more readily available on a timely basis than contracted herbicide spraying services. Additionally, mowing prior to seed maturity was a more distinct timing standard to meet than herbicide treatment at the correct weed growth stage. These obşervations highlight the utility of pre- plant or pre-emergence treatment with residual herbicides on tolerant grasses.

Observation of composition within the non-seeded species group revealed an additional trend that may have influenced diversity results. Under auxin herbicide and mowing treatments, nearly all nonseeded species were comprised of annual broadleaf weed species such as kochia (Kochia americana S. Wats.), Russian thistle (Salsola iberica L.), common annual sunflower (Helianthus annuus L.), and prickly lettuce (Lactuca serriola L.). In contrast, non-seeded species composition under sulfonylurea herbicide treatment was dominated by perennial broadleaf weeds, perennial half-shrubs, and annual and perennial grasses. These species included milkvetch (Astragalus spp.), perennial thistle (Cirsium spp.), scarlet globemallow [Sphaeralcea coccinea (Nutt.) Rydb.], broom snakeweed [Gutierrezia sarothrae (Pursh.) Britt. \& Rusby], curlycup gumweed [Grindelia squarrosa (Pursh) Dunal], Louisiana sagewort [Artemisia ludoviciana Nutt.), fringed sagewort (Artemisia frigida Willd.), Texas tumblegrass [Schedonnardus paniculatus (Nutt.) TreL], red threeawn (Aristida longiseta Steud.), and bottlebrush squirreltail [Elymus elymoides (Raf.) Swezey]. Differences in seeded and non-seeded species composition between treatments were readily apparent a minimum of 7 years post-treatment, emphasizing the long duration of herbicide effects. More importantly, the predominance of later-seral species under sulfonylurea herbicide treatment suggests that secondary successional status for non-seeded species has been dramatically accelerated.

\section{Conclusions}

Impacts of 2 commonly used sulfonylurea residual herbicides and 2 auxin herbicides on establishment, inter-specific seedling competition and physiological response under CRP field conditions were evaluated. Seeded species were blue grama [Bouteloua gracilis (Willd). Ex Kunth) Lag. ex Griffiths], sideoats grama [Bouteloua curtipendula (Michx.) Torr.], western wheatgrass [Pascopyrum smithii (Rydb.) A. Love], switchgrass [Panicum virgatum L.], and sand dropseed [Sporobolus cryptandrus (Torr.) Gray].

Sideoats grama responded positively to sulfonylurea herbicides, whereas switchgrass and western wheatgrass were adversely affected. Switchgrass cover was reduced by application of either sulfony- lurea or auxin herbicides. Blue grama and sand dropseed were least affected by herbicide treatment. Plant diversity was reduced under sulfonylurea treatment. Auxin herbicide treatment increased plant diversity for seeded species and total plant community over sulfonylurea treatment, which was primarily attributable to increased frequency of annual forbs. Secondary successional status for nonseeded species was dramatically accelerated under sulfonylurea herbicide treatment, however, because of increased frequency, cover and live standing crop of perennial forbs, grasses, and half-shrubs.

The increased dominance of sideoats grama and reduction of western wheatgrass and switchgrass in seeded CRP plant communities treated with sulfonylurea herbicides suggests that composition shifts within mixtures containing these species, in both initial establishment and long-term duration, may be achieved with the application of sulfonylurea herbicides.

\section{Literature Cited}

Afifi, A.A. and V. Clark. 1984. Computeraided multivariate analysis. Lifetime Learning Pub., Belmont, Calif.. 458pp.

Anderson, D.L., J.G. Lesh, and D.W. Wickman. 1981. Soil survey of Kiowa County, Colorado. USDA Soil Conserv. Serv., Denver, Colo. 125pp.

Beyer, E.M. Jr., M.J. Duffy, J.V. Hay, and D.D. Schlueter. 1988. Sulfonylureas, p. 117-189. In: Kearney, P.C. and D.D. Kaufman (eds) Herbicides - chemistry, degradation, and mode of action, Vol. 3. Marcel Dekker, Inc., New York, N.Y.

Bonham, C.D. 1989. Measurements for terrestrial vegetation. John Wiley and Sons, New York, N.Y. 338pp.

Bovey, R.W. and M.A. Hussey. 1991. Response of selected forage grasses to herbicides. Agron. J. 83:709-713.

Brown, H.M. and J.C. Cotterman. 1994. Recent advances in sulfonylurea herbicides, p. 47-81. In: Stetter, J. (ed) Chemistry of plant protection, vol. 10 - herbicides inhibiting branched-chain amino acid biosynthesis recent developments. Springer-Verlag, New York, N.Y.

Brown, H.M., T.P. Fuesler, T.B. Ray, S.D. Strachan, and H. Frehse. 1991. Role of plant metabolism in crop selectivity of herbicides, p. 257-266. In: Frehse, H. (ed) Pesticide chemistry: advances in international research, development, and legislation. Proc. $7^{\text {th }}$ Int. Congr. of Pest. Chern. (IUPAC). Weinheim, Germany.

Conrad, K. 1990. Arkansas Valley revegetation project 1990 annual progress report. USDA Nat. Resources Conserv. Serv., Rocky Ford, Colo. 67pp. 
Cook, C.W. and J. Stubbendieck. 1986. Range research: basic problems and techniques. Soc. Range Manage., Denver, Colo. $317 \mathrm{pp}$.

Darwent, A.L. and G.W. Clayton. 1994. Response of five perennial forage crops to residues of metsulfuron and chlorsulfuron in northern Alberta. Forage Notes 37:16-25.

Daubenmire, R. 1959. A canopy-coverage method of vegetational analysis. Northwest Sci. 19 33(1):43-64.

Dixon, W.J. (ed). 1992. BMDP release 7 statistical software manual. Univ. California Press, Berkeley, Calif.. 1500 pp.

Downs, J.A. and G.C. Niner. 1963. Conservation plant materials technical note no. 9 - sideoats grama, Bouteloua curtipendula. USDA Soil Cons. Serv., Colo. 3pp. Ferrell, M.A, T.D. Whitson, D.W. Koch, and A.E. Gade. 1998. Leafy spurge (Euphorbia esula) control with several grass species. Weed Technol. 12:374-380.

Ferrell, M.A., T.D. Whitson, D.W. Koch, and A.E. Gade. 1998. Leafy spurge (Euphorbia esula) control with several grass species. Weed Technol. 12:374-380.

Francis, M.G. and D.A Pyke. 1997. Mixeddensity designs for evaluating plant interactions during revegetation. Rangelands 19:23-26.

Goatley, J.M. Jr., AJ. Powell Jr., M. Barrett, and W.W. Witt. 1991. Absorption, translocation, and metabolism of chlorsulfuron in Kentucky bluegrass and tall fescue. J. Amer. Soc. Hort. Sci. 115:771-774.

Gomez, K.A and A.A Gomez. 1984. Statistical procedures for agricultural research. John Wiley and Sons, New York, N.Y. 679 pp.

Heizer, R.B. and W.G. Hassell. 1985. Improvement of the gramas and other shortgrass prairie species, p. 63-69. In: Carlson, J.R., and E.D. McArthur (eds) Range plant improvement in western North America. Symp. Proc., Soc. for Range Manage. Ann. Meet., Salt Lake City, Utah. 14 February 1985.

Hyder, D.N., AC. Everson, and R.E. Bement. 1971. Seedling morphology and seeding failures with blue grama. J. Range Manage. 24:287-292.

Jones, R.D., P.D. Ohlenbusch, and J. Tranel. 1997. Proposed CRP policy: ontrack or a source of 3 concern. Rangelands 19: 13-15.

Kline, V.A. and E.A. Howell. 1987. Prairies, p.75-83. In: Jordan, W.R. III, M.E. Gilpin, and J.D. Aber (eds) Restoration Ecology, a synthetic approach to ecological research. Cambridge Univ. Press, Cambridge.

Knight, W.G., J.A. Morgan, W.D. Guenzi, and M.C. Shoop. 1993. Soil-applied atrazine alters blue grama physiology and indirectly influences soil nitrogen. Agron. J. 85: 1 029-1 035 .

Lym, R.G. 1998. The biology and integrated management of leafy spurge (Euphorbia esula) on North Dakota rangeland. Weed Technol. 12:367-373.

Machac, J. 1995. Effect of stand treatment by sulfonylureas on grass seed yields. Rostlinna Vyroba 41 547-551.
Manly, B.F.J. 1994. Multivariate statistical methods, a primer. Chapman and Hall, New York, N.Y. 215 pp.

McGinnies, W.J., W.A. Laycock, T. Tsuchiya, C.M. Yonker, and D.A. Edmunds. 1988. Variability within a native stand of blue grama. J. Range Manage. 41:391-395.

McLendon, T. and B.E. Dahl. 1983. A method for mapping vegetation utilizing multivariate statistical techniques. J. Range Manage. 36:457-462.

Ogg, A.G. Jr., S.B. Monsen, and S.G. Kitchen. 1994. A review of the chemical control of downy brome, p. 194-196. In: Monsen, S.B. (ed) Proc. - ecology and management of annual rangelands. USDA Forest Servo Intermountain Forest and Range Exp. Sta. Rep. INT - 313.

Olmstead, C.E. 1941. Growth and development in range grasses. I. Early development of Bouteloua curtipendula in relation to water supply. Bot. Gaz. 102:499-519.

Olmstead, C.E. 1942. Growth and development in range grasses. II. Early development of Bouteloua curtipendula as affected by drought periods. Bot. Gaz. 103 531-542.

Osborn, C.T., F. Llacuna, and $M$. Linsenbigler. 1995. The Conservation Reserve Program: enrollment statistics for the signup periods $1-12$ and fiscal years 1986-93. USDA Econ. Res. Servo Stat. Bull. No. 925.102 pp.

Riddel, M., M.D. Skold, and W.L. Trock. 1994. The future ofthe Conservation Reserve Program in Colorado. Colo. St. Univ. Agr. Exp. Sta. Rep. TR94-5. 41 pp.

Simpson, E.H. 1949. Measurement of diversity. Nature 163:688.

Sims, P.L., LJ. Ayuko, and D.N. Hyder. 1971. Developmental morphology of switch grass and sideoats grama. J. Range Manage. 24:357-360.

Steel, R.G.D. and J.R. Torrie. 1980. Principles and procedures of statistics - a biometric approach. McGraw-Hill Pub!. Co., New York, N.Y. 633 pp.

Stougaard, R.N., R.A. Masters, and S.J. Nissen. 1994. Leafy spurge (Euphorbia esula) control with imidazolinone and sulfonylurea herbicides. Weed Technol. 8:494-498.

Taylor, J.E. 1986. Cover data in monitoring rangeland vegetation, p. 15-24. In:Smith, E.L., S.S. Coleman, C.E. Lewis, and G.W. Tanner (eds) Use of cover, soils and weather data in rangeland monitoring symposium proceedings. February 1986, Kissimmee, Fla. Soc. Range Manage., Denver, Colo. 46 pp.

Tober, D.A. and A. D. Chamrad. 1992. Warm-season grasses in the northern Great Plains. Rangelands 14:227-230.

USDA, NRCS. 2001. The PLANTS Database, Version 3.1 (http://plants.usda.gov; 1 September 2001). National Plant data Center, Baton Rouge, La. 70874-4490 USA.

Walker, A., E.G. Cotterill, and S.J. Welch. 1989. Adsorption and degradation of chlorsulfuronand metsulfuron-methyl in soils from different depths. Weed Res. 29:281-287.
Wauchope, RD., T.M. Buttler, A.G. Hornsby, P.W.M. Augustun-Beckers, and J.P. Burt. 1992. The SCSI ARS/CES pesticide properties database for environmental decision making, p. 1-164. In: Ware, G.W. (ed) Reviews of environmental contamination and toxicology, vol. 123. SpringerVerlag, New York, N.Y.

Weimer, M.R and B.A. Swisher. 1985. Metabolism of atrazine in big bluestem, indiangrass, sideoats grama and switchgrass as a basis for differential toxicity. Proc. North Central Weed Control Conf. 40:121-122.

Whitson, T.D. and D.W. Koch. 1998. Control of downy brome (Bromus tectorum) with herbicides and perennial grass competition. Weed Technol. 12:391-396.

Wilson, RG. 1995. Effect of imazethapyr on perennial grasses. Weed Technol. 9: 187-191.

Wilson, A.M. and D.D. Briske. 1979. Seminal and adventitious root growth of blue grama 16 seedlings on the Central Plains. J. Range Manage. 32:209-213.

Zimdahl, R.L. 1993. Fundamentals of weed science. Academic Press, Inv., New York, N.Y. 450 pp. 